\title{
Use of Latent autoimmune diabetes in adults clinical risk score in type 2 diabetes
}

\author{
R. Anil Kumar ${ }^{1}$, Surekha B Shetty ${ }^{2}$, Lalitha $\mathbf{R}^{3}$ \\ ${ }^{1}$ Dr R. Anil Kumar, Consultant Diabetologist, ${ }^{2}$ Dr Surekha B. Shetty, Consultant Diabetologist. ${ }^{3}$ Dr R. Lalitha Consultant \\ Diabetologist, All authors are affiliated to Karnataka Institute of Endocrinology and Research Bangalore, Karnataka, \\ India.
}

Address for Correspondence: Dr R. Anil Kumar, Email: r.anil_kumar@yahoo.co.in

\begin{abstract}
Background: Subjects with type 2 diabetes may harbour islet auto antibodies and this has implications on progression of disease and therapeutic options. Clinical tools to distinguish antibody positive individuals are essential to guide the therapy. Objective: To develop a clinical risk score in subjects with Type 2 Diabetes to identify LADA. Methods: We studied 100 persons aged between 25 to 65 years diagnosed as Type 2 Diabetes by FBS $>126 \mathrm{mg} / \mathrm{dl}$ and C-peptide $>0.6$ ng/ml. Results: $17 \%$ of Type 2 Diabetic individuals were GAD positive. 11 were males and 6 were females. GAD positivity in the 25 to 34 years age group was $16.3 \%, 35$ to 44 years age group was $20.8 \%, 45$ to 54 years age group was $21.1 \%$, and in $>55$ was $0 \%$ respectively. GAD positivity with respect to the duration of diabetes $0-5$ years, $5-10$ years and $>10$ years was $18.2,12.3$ and $20 \%$ respectively. $82.4 \%$ of GAD positive type 2 diabetes individuals had BMI $<25$ $\mathrm{kg} / \mathrm{m}^{2}$ and age of onset of diabetes $<50$ years. Mean BMI, waist circumference and fasting C-peptide were 24.86 \pm 4.66 , $87.55 \pm 10.78$ and 2.49 \pm 1.41 in GAD negative Type 2 Diabetics. Mean BMI, waist circumference and fasting C-peptide were $21.65 \pm 3.46,80.20 \pm 10.03$ and $3.04 \pm 3.66$ in GAD positive Type 2 Diabetics. All 17 GAD positive patients had LADA clinical risk score of 2 or more, So this score should be used in the clinic to suspect LADA patients. Conclusions: LADA clinical risk score is $\geq 2$ in all 17 GAD antibody positive subjects with Type 2 Diabetes. So this scoring system can be used as a tool to suspect LADA patients in the clinical setting. A multicentre study is necessary to further validate this scoring system.
\end{abstract}

Keywords: GAD anti body, LADA, Type 2 diabetes, C-Peptide

\section{Introduction}

Glutamic acid decarboxylase, abbreviated as GAD is an enzyme that makes GABA, a neurotransmitter substance that is also present in the brain. As a result of the beta cell attack, antibodies to GAD appear in the blood and can nowadays be measured with simple but very sensitive and reliable tests. Two forms of antiglutamic acid decarboxylase (GAD antibody) exist, having molecular size of 65 and the other $67 \mathrm{kDa}$. Antibodies to GAD 65 are specific for diabetes. 50\% of Type 2 diabetes patients with GAD antibodies are labelled as Latent autoimmune diabetes in adults (LADA) and will require insulin to control their diabetes within few years of diagnosis.

Manuscript received: $5^{\text {th }}$ February 2017

Reviewed: $14^{\text {th }}$ February 2017

Author Corrected: $20^{\text {th }}$ February 2017

Accepted for Publication: $28^{\text {th }}$ February 2017
The clinical features of LADA include [1]. :

1. Age $\geq 25$ years.

2. Clinical presentation of non-obese type 2 diabetes.

3. Initial control achieved with diet alone or diet and oral hypoglycaemic agents.

4. Insulin dependency within months but take 10 years or more.

5. Other features of type 1 diabetes like low fasting and post glucagon stimulated c-peptide, HLA susceptibility alleles, ICA+ or GADA+.

Patients with high GADA titers $>20 \mathrm{U} / \mathrm{ml}$ may benefit from early insulinization and avoiding use of sulfonylurea, delaying beta cell failure. In contrast, 
patients with low GADA titers $<20 \mathrm{U} / \mathrm{ml}$ do not seem to have any disadvantage when managed as other type 2 diabetics [2].

\section{Materials and Methods}

This study was performed at Karnataka Institute of Endocrinology and Research, Bangalore over a period of 18 months. Informed consent was obtained from all the participants. All the 100 participants had Type 2 Diabetes, diagnosed by FBS $\geq 126 \mathrm{mg} / \mathrm{dl}$ and C-peptide levels $>0.6$ nanogm $/ \mathrm{ml}$. Detailed history was taken and clinical examination was done by doctors.

Anthropometric measurements were measured by trained nurses. Weight and height of each participant was measured and the BMI was calculated using the formula body weight in kilograms divided by height in square meters. Waist circumference was measured at the level of midpoint between the lowest margin of the rib and the iliac crest in a standing position. The participants were required to rest for at least 5 minutes before having their blood pressure checked. Fasting blood samples were collected from an ante cubital vein in plain tubes in the morning after 8 hours overnight fast. Blood glucose was estimated using GOD-POD method. (HITACHI 912 AUTO ANALYSER) Fasting c-peptide levels estimated by electrochemiluminescence. GAD antibody levels estimated using EUROIMMUN anti-GAD ELISA test. The upper limit of normal range recommended by EUROIMMUN is 10 international units per milliliter. EUROIMMUN recommends interpreting results as follows-- $<10 \mathrm{IU} / \mathrm{ml}$ as negative and $\geq 10 \mathrm{IU} / \mathrm{ml}$ as positive. The GAD antibody content in 250 sera (origin- Germany) was assessed both by ELISA and RIA as reference method. The sensitivity of ELISA was $96 \%$ with a specificity of $98 \%$ referring to the RIA.

Statistical Methods: Descriptive statistical analysis has been carried out in the present study. Results on continuous measurements are presented on Mean \pm SD (Min-Max) and results on categorical measurements are presented in Number (\%). Significance is assessed at $5 \%$ level of significance.

Student t test (two tailed, independent) has been used to find the significance of study parameters on continuous scale between two groups (Inter group analysis) on metric parameters. Chi-square/ Fisher Exact test has been used to find the significance of study parameters on categorical scale between two or more groups.

\section{Results}

Table-1: Baseline characteristics of the study population.

\begin{tabular}{|c|c|c|c|}
\hline Parameter & Category & Number of patients & Percentage \\
\hline \multirow{3}{*}{ Gender } & Male & 68 & 38.0 \\
\cline { 2 - 4 } & Female & 32 & 11.0 \\
\hline \multirow{2}{*}{ BMI $\left(\mathbf{k g} / \mathbf{m}^{\mathbf{2}}\right)$} & $<18.5$ & 41 & 41.0 \\
\cline { 2 - 4 } & $18.5-25.0$ & 37 & 37.0 \\
\cline { 2 - 4 } & $25.0-30.0$ & 11 & 11.0 \\
\hline \multirow{3}{*}{ Age in years } & $>30.0$ & 49 & $49.0 \%$ \\
\cline { 2 - 4 } & $25-34$ & 24 & $24.0 \%$ \\
\cline { 2 - 4 } & $35-45$ & 19 & $19.0 \%$ \\
\cline { 2 - 4 } & $45-54$ & 8 & $8.0 \%$ \\
\hline \multirow{3}{*}{ Duration of DM } & $55 \&$ above & 66 & $66.0 \%$ \\
\cline { 2 - 4 } & $0-5$ years & 24 & $24.0 \%$ \\
\cline { 2 - 4 } & $>5-10$ years & 10 & $10.0 \%$ \\
\hline
\end{tabular}

Among 100 subjects studied, $68 \%$ were males and $32 \%$ were females. $37 \%$ of the subjects had BMI $>25$, while $52 \%$ of the subjects had BMI $<25.49 \%$ of the subjects were between the age group of 25 to 35 years. $66 \%$ of the subjects had duration of diabetes $<5$ years (Table 1 ). 
Table-2: Incidence of GAD of individuals studied.

\begin{tabular}{|c|c|c|}
\hline GAD & Number of patients & \% \\
\hline Yes & 17 & 17.0 \\
\hline No & 83 & 83.0 \\
\hline Total & 100 & 100.0 \\
\hline
\end{tabular}

Table 2 shows that $17 \%$ of subjects with type 2 diabetes had GAD antibodies positivity with titres ranging from 12.9 to $>2000$. 11 of them were males and 6 were females.

Table-3: Correlation of Clinical variables according to incidence of GAD.

\begin{tabular}{|c|c|c|c|}
\hline \multirow{2}{*}{ Clinical variables } & \multicolumn{2}{|c|}{ GAD } & \multirow{2}{*}{ P value } \\
\cline { 2 - 3 } & No & Yes & 0.432 \\
\hline Age in years & $38.40 \pm 10.44$ & $36.24 \pm 9.45$ & 0.749 \\
\hline Gender (M:F) & $57: 26$ & $11: 6$ & 0.299 \\
\hline Fasting C- Peptide & $2.49 \pm 1.41$ & $3.04 \pm 3.66$ & $0.011^{* *}$ \\
\hline Waist $(\mathrm{cm})$ & $87.55 \pm 10.78$ & $80.20 \pm 10.03$ & $0.009^{* *}$ \\
\hline BMI $(\mathrm{kg} / \mathrm{m} 2)$ & $24.86 \pm 4.66$ & $21.65 \pm 3.46$ & \\
\hline
\end{tabular}

+ Suggestive significance $(\mathrm{P}$ value: $0.05<\mathrm{P}<0.10)$

* Moderately significant ( $\mathrm{P}$ value: $0.01<\mathrm{P} \leq 0.05$ )

** Strongly significant $(\mathrm{P}$ value: $\mathrm{P} \leq 0.01)$

The mean BMI, waist circumference and fasting c-peptide were $24.86 \pm 4.66,87.55 \pm 10.78$ and $2.49 \pm 1.41$ in GAD negative subjects with type 2 diabetes. Mean BMI, waist circumference and fasting c-peptide were 21.65 \pm 3.46 , $80.20 \pm 10.03$ and 3.04 \pm 3.66 in GAD positive subjects with type 2 diabetes. BMI and waist circumference were statistically significantly lower in GAD positive subjects ( $p$ value -0.009 and 0.001 ). Mean fasting c-peptide was higher in the GAD positive group because five subjects had higher fasting c-peptide levels of 3.64, 3.84, 5.19, 5.85 and 16.01. Table 3.

With regard to age distribution of GAD positivity, it was found that GAD positivity in $16.3 \%$ in 25 to 34 years age group, $20.8 \%$ in 35 to 44 years group, $21.1 \%$ in 45 to 54 years group and $0 \%$ in age group above 55 years respectively. Type 2 diabetes individuals with duration of diabetes less than 5 years had 18.2\% GAD positivity and diabetics with 5 to 10 years had $12.5 \%$ positivity while individuals with more than 10 years had $20 \%$ GAD positivity. $82.4 \%$ of GAD positive individuals had BMI $<25 \mathrm{~kg} / \mathrm{sqmt}$ and age of onset of diabetes $<50$ years.

Table-4: LADA clinical risk score in the patients studied.

\begin{tabular}{|c|c|}
\hline Criteria & Number of patients \\
\hline Age $<50$ years & 14 \\
\hline BMI <25 KG/SQMT & 13 \\
\hline Acute symptoms of hyperglycemia & 17 \\
\hline Family h/o autoimmune disease & 0 \\
\hline Personal h/o autoimmune disease & 0 \\
\hline 2 or more score & 17 \\
\hline
\end{tabular}

LADA clinical risk score includes clinical features like age of onset<50 years; acute symptoms of hyperglycemia; BMI < $25 \mathrm{~kg} / \mathrm{sqmt}$; personal history of autoimmune disease; family history of autoimmune disease as the criteria for diagnosis for LADA.Table 4 
Table 5: Details of GAD Positive Type 2Diabetes.

\begin{tabular}{|c|c|c|c|c|c|c|c|c|}
\hline & Age & Sex & BMI & $\begin{array}{l}\text { WCR IN } \\
\text { CMS }\end{array}$ & $\begin{array}{l}\text { Duration of DM } \\
\text { in years }\end{array}$ & $\begin{array}{c}\text { Fasting C-peptide In } \\
\text { Nano gram/ml }\end{array}$ & $\begin{array}{c}\text { GAD AB } \\
\text { IU/ML }\end{array}$ & $\begin{array}{l}\text { Family } \\
\text { History }\end{array}$ \\
\hline 1 & 25 & $\mathrm{~F}$ & 22 & 79 & 2 & 0.925 & 314.7 & - \\
\hline 2 & 25 & $\mathrm{M}$ & 17 & 67.7 & 1 & 1.6 & 19 & - \\
\hline 3 & 25 & $\mathrm{~F}$ & 21 & 77 & 2 & 1.4 & 17.3 & - \\
\hline 4 & 28 & $F$ & 17 & 65.3 & 2 & 3.64 & 111.6 & - \\
\hline 5 & 28 & $\mathrm{M}$ & 22 & 84 & 0.5 & 5.19 & 14.2 & + \\
\hline 6 & 31 & $\mathrm{M}$ & 24 & 84.9 & 9 & 2.2 & 13.8 & + \\
\hline 7 & 32 & $\mathrm{M}$ & 16 & 64 & 3 & 1.25 & 122.1 & - \\
\hline 8 & 32 & $\mathrm{M}$ & 19 & 78.4 & 0.83 & 1.23 & 12.9 & - \\
\hline 9 & 33 & $\mathrm{M}$ & 17 & 72.8 & 4 & 0.623 & $>2000$ & + \\
\hline 10 & 35 & $\mathrm{M}$ & 24 & 81 & 1 & 1.76 & 1800 & + \\
\hline 11 & 35 & $\mathrm{M}$ & 25 & 85 & 0.5 & 3.84 & 42.6 & - \\
\hline 12 & 35 & $\mathrm{~F}$ & 22 & 80 & 8 & 1.8 & 15.5 & - \\
\hline 13 & 42 & $\mathrm{M}$ & 26 & 96 & 0.5 & 16.01 & 32.7 & + \\
\hline 14 & 48 & $\mathrm{M}$ & 26 & 95.6 & 1 & 5.85 & 12.9 & - \\
\hline 15 & 51 & $\mathrm{M}$ & 20 & 74.6 & 13 & 1.6 & $>2000$ & - \\
\hline 16 & 51 & $\bar{F}$ & 26 & 98.4 & 10 & 1.75 & 1928 & + \\
\hline 17 & 52 & $\mathrm{~F}$ & 24 & 80 & 6 & 1.1 & $>2000$ & + \\
\hline
\end{tabular}

\section{Discussion}

Latent autoimmune diabetes in adults (LADA) is a special category of adult-onset diabetes that is characterised by features of both type 1 and type 2 diabetes. Diagnosing LADA has important clinical implications because of the high risk of progression to insulin dependency. Antibody testing is the diagnostic investigation for LADA. But, several studies have looked at clinical screening tools to identify adults with diabetes who require antibody testing.

In the United Kingdom Prospective Diabetes Study (UKPDS) of 3,762 white subjects with recently diagnosed type 2 diabetes (based on clinical criteria), $10 \%$ had anti-GAD antibodies at the time of diagnosis [3]. In the 'A Diabetes Outcome Progression Trial' (ADOPT) the prevalence of GAD antibody positivity was $4.2 \%$, and there was no difference in the prevalence of these antibodies in North America and Europe (4.7 and $3.7 \%$, respectively) [4]. In the Botnia Study in western Finland, the prevalence of GAD positivity was $9 \%$ [5]. The finding of a prevalence in ADOPT study of $3.7 \%$ in Europe is clearly lower than that found in the UKPDS and Botnia Study. A Swedish study showed that 70 of 97 patients assumed to have type 2 diabetes at onset required insulin after 6 years. GAD antibodies were present in $60 \%$ of these patients compared with $7 \%$ in those who did not require insulin (6). In a study in Icelandic population about $10 \%$ of Icelandic type 2 diabetic individuals had antibodies against GAD, which is comparable to the results of our study. Icelandic GAD positive type 2 diabetic individuals have less frequently the metabolic syndrome than other type 2 diabetic individuals and GAD positive individuals are significantly more related to each other than type 2 diabetic individuals in general [7]. Tuomi et al showed that the prevalence of GAD positivity was $9.3 \%$ among 1,122 type 2 diabetic patients, $3.6 \%$ among 558 impaired glucose tolerance (IGT) subjects, and $4.4 \%$ among 383 non diabetic control subjects [8]. The prevalence of GAD positivity was $17.7 \%$ in Latakia in Syria [9]. The prevalence of GAD Antibody in Japanese patients with short and long history of type 2 diabetes was $2.8 \%$ and $0.9 \%$ [10].

A South Indian study showed that the frequency of GAD65 antibodies was $21 \%$ [11]. Alexandra Sima et.al showed that according to LADA characteristics, 28 of the 268 subjects of their group $(10.4 \%)$ were positive for at least one pancreatic autoantibody and has developed insulin dependence after at least 6 months of 
diabetes evolution [12]. The prevalence of anti GAD positive patients in Dutch teaching hospital was $11.6 \%$ in type 2 diabetic population. [13].

LADA clinical risk score was formulated by Spiros Fourlanos in a retrospective study titled a clinical screening tool identifies autoimmune diabetes in adults [14]. LADA clinical risk score includes clinical features like age of onset $<50$ years; acute symptoms of hyperglycemia; BMI < $25 \mathrm{~kg} / \mathrm{sqmt}$; personal history of autoimmune disease; family history of autoimmune disease as the criteria for diagnosis for LADA. The presence of at least two of these distinguishing clinical features in type 2 diabetes that is LADA risk score $\geq 2$ had $90 \%$ sensitivity for identifying LADA.

In our study, the prevalence of GAD positivity is $17 \%$ with $7 \%$ having low titres of $<20 \mathrm{IU} / \mathrm{ml}$. $82.4 \%$ of GAD positive type 2 diabetes individuals had BMI $<25$ and age of onset as $<50$ years and all subjects had symptoms of hyperglycemia. This suggests that it is necessary to test for GAD antibodies in selected subjects with type 2 diabetes, with age of onset $<50$ years, BMI $<25$ and acute symptoms of hyperglycemia. If they are GAD positive with high titres, insulin therapy can be started as early as possible to prevent progression of beta cell damage. 12 GAD positive patients have LADA clinical risk score of 3 and 5 patients have 2. All GAD positive patients in our study had LADA clinical risk score of 2 or more, so this score should be used in the clinic to suspect LADA patients and subject them for C-peptide and GAD antibody tests.

\section{Conclusions}

In this study we find a prevalence of GAD antibody positivity present in $17 \%$ of type 2 diabetes, with high titres in $10 \%$ of patients, such patients require insulin earlier. These patients if identified early can guide us in therapy by introducing insulin earlier, as the response to oral hypoglycaemic drugs may not be optimal.

All 17 patients had symptoms of hyperglycemia, 14 patients age was less than 50 years and 13 patients BMI was less than $25 \mathrm{~kg} / \mathrm{sqmt}$. Using these criteria and the laboratory tool of GAD antibody we may identify such patients early for a better therapeutic approach. LADA clinical risk score was $\geq 2$ in all 17 GAD antibody positive diabetic patients. This is a cost effective clinical tool and it can be used to suspect LADA patients in the clinical setting. This is a small study done in a single centre, so a multicentre study is necessary to further validate this scoring system.

\section{Acknowledgements}

Dr. K. P. Suresh, Scientist (Biostatistics), National Institute of Animal Nutrition \& Physiology, Bangalore560030. No potential conflicts of interest relevant to the article are reported.
Abbreviations
LADA- Latent autoimmune diabetes.
GAD- Glutamic acid decarboxylase.
ICA- Islet cell antibodies
ELISA- Enzyme linked immunosorbent assay.
RIA- Radioimmunoassay.
BMI- Body mass index.

\section{Funding: Nil, Conflict of interest: None. Permission of IRB: Yes}

\section{References}

1. Matejkova-Behanova M. Latent autoimmune diabetes in adults (LADA) and autoimmune thyroiditis. Endocr Regul. 2001 Sep;35(3):167-72.

2. Rosário PW, Reis JS, Fagundes TA, Calsolari MR, Amim R, Silva SC, Purisch S. Latent autoimmune diabetes in adults (LADA): usefulness of anti-GAD antibody titers and benefit of early insulinization. Arq Bras Endocrinol Metabol. 2007 Feb;51(1):52-8.

3. Turner R, Stratton I, Horton V, Manley S, Zimmet P, Mackay IR, Shattock M, Bottazzo GF, Holman R. UKPDS 25: autoantibodies to islet-cell cytoplasm and glutamic acid decarboxylase for prediction of insulin requirement in type 2 diabetes. UK Prospective Diabetes Study Group. Lancet. 1997 Nov 1; 350 (9087): 1288-93.

4. Zinman B, Kahn SE, Haffner SM, O'Neill MC, Heise MA, Freed MI; ADOPT Study Group. Phenotypic characteristics of GAD antibody-positive recently diagnosed patients with type 2 diabetes in North America and Europe. Diabetes. 2004 Dec; 53 (12): 3193-200.

5. Lundgren V. Type 1 family history and GAD autoantibodies in subjects without diabetes and patients with type 2 diabetes: prevalence and association with insulin deficiency and development of diabetes. 
6. Hagopian WA, Sanjeevi CB, Kockum I, LandinOlsson M, Karlsen AE, Sundkvist G, Dahlquist G, Palmer J, Lernmark A. Glutamate decarboxylase-, insulin-, and islet cell-antibodies and HLA typing to detect diabetes in a general population-based study of Swedish children. Journal of Clinical Investigation. 1995 Apr; 95(4):1505.

7. Jónsdóttir AM, Aspelund T, Sigurdsson G, Gudnason $\mathrm{V}$, Benediktsson R. [Latent autoimmune diabetes in adults in Iceland: prevalence, phenotype and relatedness]. Laeknabladid. 2005 Dec;91(12):909-14.

8. Tuomi T, Carlsson A, Li H, Isomaa B, Miettinen A, Nilsson A, Nissén M, Ehrnström BO, Forsén B, Snickars B, Lahti K. Clinical and genetic characteristics of type 2 diabetes with and without GAD antibodies. Diabetes. 1999 Jan 1;48(1):150-7.

9. Al-Farwi AA, Khayat MI, MMuhsen AM. Latent autoimmune diabetes of adults in Latakia, Syria. International Journal of Endocrinology and Metabolism. 2010 Jan; 2010 (1, Winter):13-21.

10. Takino H, Yamasaki H, Abiru N, Sera Y, Abe T, Kawasaki E, Yamaguchi Y, Eguchi K, Kanazawa Y, Nagataki S. Antibodies to GAD in Japanese patients classified as Type 2 diabetes at diagnosis. High titre of $\mathrm{GAD} \mathrm{Ab}$ is a predictive marker for early insulin treatment-report of west Japan (Kyushu, Yamaguchi, Osaka) study for GAD Ab (+) diabetes. Diabetic medicine. 2002 Sep 1;19(9):730-4.

11. Sanjeevi CB, Balaji M, Balaji V, Seshiah V. Autoantibodies to GAD65 and IA-2 Antibodies Are Increased, but Not Tissue Transglutaminase (TTG-Ab) in Type 2 Diabetes Mellitus (T2DM) Patients from South India. Annals of the New York Academy of Sciences. 2003 Nov 1;1005(1):387-9.

12. Sima A, Rosu M, Vlad A, Silberberg G, Serban V. Latent Autoimmune Diabetes in Adults (LADA). TMJ. 2003;53:241-5.

13. Romkens TE, Kusters GC, Netea MG, Netten PM. Prevalence and clinical characteristics of insulintreated, anti-GAD-positive, type 2 diabetic subjects in an outpatient clinical department of a Dutch teaching hospital.

14. Fourlanos S, Perry C, Stein MS, Stankovich J, Harrison LC, Colman PG. A clinical screening tool identifies autoimmune diabetes in adults. Diabetes care. 2006 May 1;29(5):970-5.

\section{How to cite this article?}

R. Anil Kumar, Surekha B Shetty, Lalitha R.Use of Latent autoimmune diabetes in adults clinical risk score in type 2 diabetes. Int J Med Res Rev 2017;5(02):188-193 doi:10.17511/ijmrr. 2017.i02.14. 